\title{
1 Toxicoproteomic evaluation of carbon nanomaterials in vitro
}

2

3 Hisao Haniu a,*, Yoshikazu Matsuda b, Yuki Usui c, Kaoru Aoki c, Masayuki Shimizu c,

4 Nobuhide Ogihara c, Kazuo Hara c, Masanori Okamoto c, Seiji Takanashi c, Norio

$5 \quad$ Ishigaki c, Koichi Nakamura c, Hiroyuki Kato ${ }^{c}$ and Naoto Saito d

6

7 a Institute of Carbon Science and Technology, Shinshu University, 3-1-1 Asahi,

8 Matsumoto, Nagano 390-8621, Japan

9 b Integrative Medicine Educational Center, Nihon Pharmaceutical University, 10281

10 Komuro, Ina-machi, Saitama 362-0806, Japan

11 c Department of Orthopaedic Surgery, Shinshu University School of Medicine, 3-1-1

12 Asahi, Matsumoto, Nagano 390-8621, Japan

13 d Department of Applied Physical Therapy, Shinshu University School of Health

14 Sciences, 3-1-1 Asahi, Matsumoto, Nagano 390-8621, Japan

16 * To whom correspondence should be addressed: Hisao Haniu

17 Institute of Carbon Science and Technology, Shinshu University

18 3-1-1 Asahi, Matsumoto, Nagano 390-8621, Japan 
19 Tel: +81-263-37-2659; Fax: +81-263-35-8844

20 E-mail: hhaniu@shinshu-u.ac.jp

21

22 Keywords

23 Toxicoproteomics; Chronic toxicity; Carbon nanotubes; Nanomaterials; in vitro 
24 Carbon nanotubes (CNTs) have already been successfully implemented in various fields,

25 and they are anticipated to have innovative applications in medical science. However,

26 CNTs have asbestos-like properties, such as their nanoscale size and high aspect ratio

27 (>100). Moreover, CNTs may persist in the body for a long time. These properties are

28 thought to cause malignant mesothelioma and lung cancer. However, based on

29 conventional toxicity assessment systems, the carcinogenicity of asbestos and CNTs is

30 unclear. The reason for late countermeasures against asbestos is that reliable,

31 long-term safety assessments have not yet been developed by toxicologists. Therefore, a

32 new type of long-term safety assessment, different from the existing methods, is needed

33 for carbon nanomaterials. Recently, we applied a proteomic approach to the safety

34 assessment of carbon nanomaterials. In this review, we discuss the basic concept of our

35 approach, the results, the problems, and the possibility of a long-term safety assessment

36 for carbon nanomaterials using the toxicoproteomic approach. 


\section{Conventional Safety assessments of CNTs}

39 During the past 10 years, many studies have examined the toxicity of CNTs in vivo and in vitro (Table 1). Cytotoxicity, cytokine production and oxidative stress occur when various types of cells are cultured with CNTs [1-5]. Pulmonary exposure to CNTs caused rats and mice to develop fibrosis, granulation and inflammation in their lungs [6-8].

Takagi et al. found that the intraperitoneal injection of CNTs into p53 mice caused malignant mesothelioma [9], and Poland et al. reported that CNTs exhibit asbestos-like pathogenicity in mice [10]. However, published replies to these reports questioned the appropriateness of the administration sites or CNT dosage [11, 12]. Moreover, Muller et al. found no carcinogenic response to CNTs placed in the peritoneal cavity of rats for 2 years [13]. Many factors may be responsible for these conflicting results, but we do not yet have sufficient information about the factors that contribute to CNT toxicity in rodents or in cell culture [6].

Biological responses to CNTs are affected by multiple properties that include length, shape (single-wall or multi-wall), fibrous surface area, aspect ratio and aggregability with or without the involvement of dispersion medium [10, 14-22]. Impurities, such as iron and polycyclic aromatic hydrocarbons, are introduced into CNTs by the production process. These impurities have intrinsic toxicities, and their interaction with CNTs in 
cells can be cytotoxic [23-26]. Conventional methods suitable for the examination of acute or subacute toxicity have been used to examine the properties of CNTs that contribute to biological responses.

59 Mesothelioma caused by asbestos exposure cannot be reliably reproduced in a 60 conventional toxicity assay in vitro. Asbestos does not induce transformation of primary

61 human mesothelial cells in tissue culture. Rather, asbestos represents cytotoxicity that

62 leads the cell death to human mesothelial cells grown in vitro [27-29]. Therefore, it is

63 difficult to design an experiment that contains a positive control because the

64 mechanism for the development of mesothelioma remains unclear [30]. Essentially, the present scientific evidence is insufficient to conclude the possible long-term toxic effects of CNTs, such as development of mesothelioma.

67 Animal experiments used to evaluate chronic toxicity are also controversial. When

68 CNTs are greater than $5 \mu \mathrm{m}$ in length, it is thought that they are too large to reach the

69 distal portions of the lungs in mice or rats [31]. In fact, there are few reports of mesothelioma onset in rodents by asbestos exposure (especially particles $\geq 8 \mu \mathrm{m}$ in

71 length $\leq 0.25 \mu \mathrm{m}$ in width). Therefore, out of public concern, evaluating intraperitoneal injection of CNTs for the development of lung mesothelioma, commonly seen in cases of asbestos exposure, has been attempted. However, as mentioned, the effectiveness of this 
method is not without controversy. Indeed, it is difficult to predict the long-term safety procedure must be developed to evaluate the safety of long-term exposure to carbon nanomaterials containing CNTs.

\section{Safety evaluation of carbon nanomaterials by proteomics}

80 Witzmann and Monteiro-Riviere have used a proteomic approach to study the

81 biological responses of human keratinocytes to multi-walled CNTs [32]. Their analysis

82 identified proteins related to metabolism, cell signaling and stress, as well as

83 cytoskeletal elements and vesicular trafficking components. Chang et al. used a

84 proteomic analysis to study the mechanism of ultrafine carbon black-induced lung

85 injury in mice [33]. They analyzed proteins in bronchoalveolar lavage fluid and

86 identified 33 proteins, including leukemia inhibitory factor receptor (LIFR) and

87 epidermal growth factor receptor (EGFR). In these experiments, the exposure to carbon

88 nanomaterials was for less than 2 days, and cell viability [5] and total protein

89 concentration in bronchoalveolar lavage fluid had already been changed. Although it

90 may be said that these experiments evaluated the biological response of acute toxicity

91 by a proteomic approach, many of the expression-altered proteins in keratinocytes were 
related to stress or the tox/detox response, and some of the proteins were altered by jet

93 fuel exposure [34]. Although jet fuel exposure caused acute and severe toxicity, it is not

94 the focus of our goal, which is to predict the long-term toxicity of CNTs.

95 The purpose of conventional proteomics is to detect alterations in protein expression

96 at the time of dynamic physiological phenomena or in the state of disease alteration [35].

97 On the other hand, few reports have examined the altered expression of proteins when

98 the external stimulus requires a long time to elicit a biological response. Such altered

99 protein expression would almost certainly occur if a biological response is predicted. We

100 analyzed protein alterations in cells exposed to carbon nanomaterials at concentrations

101 that either suppressed or did not alter cell proliferation which is the standard indicator

102 of the acute toxicity.

103 Human monoblastic leukemia cells (U937) were exposed to three grades of multi-wall

104 CNTs (MWCNTs), As-grown, HTT1800 and HTT2800 (Table 2), and carbon black (CB;

105 particle diameter $=85 \mathrm{~nm})$ for $96 \mathrm{~h}[36,37]$. The iron and polycyclic aromatic

106 hydrocarbons in HTT1800 and HTT2800 were removed by thermally treating As-grown

107 MWCNTs at temperatures greater than $1800^{\circ} \mathrm{C}$ in argon. In our experiment, As-grown

108 MWCNTs exhibited significant inhibition of cell proliferation $(n=4)$. Therefore, we

109 thought that the As-grown MWCNTs produced a cytotoxic and/or cytostatic response ( $n$ 
$110=4)$. On the other hand, the proliferation of cells exposed to HTT1800 and HTT2800

111 tended to be inhibited, although this tendency was not statistically significant as

112 compared to the control $(n=4)$. HTT1800, with an amount of residual iron greater than

113 that of HTT2800, strongly inhibited the cell proliferation compared to HTT2800 [37].

114 CB did not affect cell proliferation at all [36]. Cell lysates were subjected to 2-DE and

115 the subsequent images were analyzed by PDquest software (Fig. 1). The proteins listed

116 in Table 3 were identified by peptide mass fingerprinting with matrix-assisted laser

117 desorption ionization time-of-flight mass spectrometry and had quantitatively

118 significant differences $(p<0.05)$ as compared to the control. The expression of many

119 proteins was altered in cells treated with HTT1800, HTT2800 or CB, a number of

120 proteins with altered expression were related to the degree of cell proliferation

121 inhibition. Altered expression of two proteins was shared by cells treated with any of the

122 three carbon materials. Expression alterations in these two proteins and an additional

12312 were shared by cells treated with either HTT1800 or HTT2800. These proteins are

124 involved in: metabolic processes, signal transduction/cell communication, response to

125 stress, transport, cell differentiation, cell cycle and cell death. It is noteworthy that

126 there are proteins related to the response to stress or cell death that are altered without

127 the suppression of cell proliferation. However, the proteins that function in cell 
128 proliferation and transcription were changed only in the case of cells exposed to

129 MWCNTs with impurities. We can speculate on the farsighted cellular conditions from

130 the current information available on function of the proteins that were altered by

131 stimulation and the remarkable quantitative changes in these altered proteins.

132 However, the function of these proteins is revealed at the time of remarkable alterations

133 in their expression. Chronic toxicity attributed to slow alterations over time cannot be

134 predicted due insufficient information on the relationship between chronic disease and

135 alterations in protein expression. On the other hand, 22 proteins altered only in

136 HTT1800 and six proteins altered only in HTT2800 and CB, respectively, may reflect

137 the cellular response to fiber or particle properties or structural defects and impurities

138 in each carbon nanomaterial. For example, annexin A2 is increased by MWCNTs but

139 decreased by CB. Annexin A2 is modulated by TLR4, resulting in the secretion of

140 inflammatory mediators [38]. The differences in the expression alteration of annexin A2

141 may be linked to cytokine production [19]. Alterations in cells that are divided two or

142 three times while continually exposed to non-biodegradable CNTs, without exhibiting

143 acute cytotoxic responses, may lead to CNT-induced chronic toxicity. Thus, we believe

144 that the proteomic technique could be used to evaluate details of proteins related to

145 CNT-induced chronic toxicity and clarify the pathophysiology of CNTs. 


\section{Problem and direction of toxicoproteomics for carbon nanomaterials}

148 In this review, we do not speculate on the toxicity of CNTs based on the functions of

149 proteins with altered expression levels, because the scientific evidence on relationships

150 between the known functions of altered proteins and chronic toxicity is overwhelmingly

151 lacking. Chronic biological responses are highly influenced by environmental factors

152 and differences in individuals, whereas most of the acute toxic responses are

153 programmed with the conserved gene. Recently, clinical proteomic profiling to search for

154 biomarkers has been undertaken [39, 40], but the correlation coefficient to an individual

155 biomarker in a chronic disease is generally lower than that of an acute disease [41, 42].

156 This fact seems to be associated with the observation that higher organisms can adapt

157 to environmental alterations because they have multiple pathways for maintaining

158 homeostasis. For example, higher organisms may not develop a disease even if a

159 diagnostic biomarker is outside of its normal range. Therefore, in toxicoproteomic

160 research, only one or a few protein biomarkers are insufficient to assess long-term

161 toxicity. As a result, the hazard of useful compounds is overestimated; a wrong

162 conclusion may be drawn. To avoid such problems, all clinical and experimental

163 proteome data with quantitative information should be compiled into a database 
without selecting specific proteins based on their degree of alteration. Multiple data

165 from the same patients in different stages of a disease and different patients in the

166 same disease stage are needed for successful applications of clinic proteomics, because

167 the homeostasis and the state of a disease are kinetically altered [35, 43]. In other

168 words, the key to the success of toxicoproteomic predictions of toxicity is the

169 construction of a database of the detailed clinical proteome. Meanwhile, proteome data

170 must be accumulated to investigate interspecies differences, individual differences and

171 tissue differences using experimental animals and cultured cells with an ultimate goal

172 of determining "personalized safety" from toxicoproteome data using novel models and

173 tools, such as induced pluripotent stem cells derived from a specific individual.

174 In this review, we mainly introduced the proteomic approaches based on the 2-DE/MS

175 strategy. Although the 2-DE/MS strategy can provide valuable information about

176 protein profile changes associated with exposure to carbon nanomaterials, it may not

177 allow for quantitative comparison of low abundant proteins. From this perspective, new

178 quantitative proteomic approaches, such as isotope-labeled or label-free quantitative

179 LC-MS/MS, also should be used to obtain more proteome information.

180

\section{Conclusion}


182 Based on the results of currently available toxicoproteomics, it is not yet clear if 183 carbon nanomaterials will be hazardous in applications in various fields, including 184 medical sciences. The most promising materials in the field of nanotechnology are 185 carbon nanomaterials; therefore, their safety assessment should be performed very 186 carefully. Carbon nanomaterials elicit different biological responses based on their 187 shape, as seen from a comparison of MWCNTs and CB. As toxicoproteome data on the 188 mechanisms of biological responses become available, the cytotoxicities of morphologically different carbon nanomaterials can be determined. The possibility of mesothelioma caused by CNTs is of particular importance; thus, a comprehensive safety assessment comprised of both toxicoproteomic analysis and other evaluation procedures should be performed. The properties of carbon nanomaterials, unlike the properties of asbestos, can be modified because the carbon nanomaterials are artificially produced.

194 Therefore, if a hazard can be precisely identified, a new carbon nanomaterial without 195 the hazardous property can be designed and produced. We believe that our lives will be 196 enhanced by the development and medical application of nonhazardous carbon 197 nanomaterials.

\section{Acknowledgements}

200 This work was supported by the Regional Innovation Cluster Program of Nagano and a

201 Grant-in-Aid (No. 19002007) from the Ministry of Education, Culture, Sports, Science and Technology of Japan. 
205 The authors declare that they have no conflicts of interest.

\section{References}

208 [1] Hirano S, Fujitani Y, Furuyama A, Kanno S. Uptake and cytotoxic effects of multi-walled 209 carbon nanotubes in human bronchial epithelial cells. Toxicol Appl Pharmacol. $210 \quad 2010 ; 249: 8-15$.

211 [2] Jacobsen NR, Pojana G, White P, Moller P, Cohn CA, Korsholm KS, et al. Genotoxicity, 212 cytotoxicity, and reactive oxygen species induced by single-walled carbon nanotubes and $213 \mathrm{C}(60)$ fullerenes in the FE1-Mutatrade markMouse lung epithelial cells. Environ Mol 214 Mutagen. 2008;49:476-87.

215 [3] Pacurari M, Yin XJ, Zhao J, Ding M, Leonard SS, Schwegler-Berry D, et al. Raw 216 single-wall carbon nanotubes induce oxidative stress and activate MAPKs, AP-1, 217 NF-kappaB, and Akt in normal and malignant human mesothelial cells. Environ Health 218 Perspect. 2008;116:1211-7.

219 [4] Pulskamp K, Diabate S, Krug HF. Carbon nanotubes show no sign of acute toxicity but 220 induce intracellular reactive oxygen species in dependence on contaminants. Toxicol Lett. $221 \quad 2007 ; 168: 58-74$.

222 [5] Monteiro-Riviere NA, Nemanich RJ, Inman AO, Wang YY, Riviere JE. Multi-walled 223 carbon nanotube interactions with human epidermal keratinocytes. Toxicol Lett. $224 \quad 2005 ; 155: 377-84$.

225 [6] Donaldson K, Aitken R, Tran L, Stone V, Duffin R, Forrest G, et al. Carbon nanotubes: a 226 review of their properties in relation to pulmonary toxicology and workplace safety. Toxicol 227 Sci. 2006;92:5-22.

228 [7] Porter DW, Hubbs AF, Mercer RR, Wu N, Wolfarth MG, Sriram K, et al. Mouse 229 pulmonary dose- and time course-responses induced by exposure to multi-walled carbon 230 nanotubes. Toxicology. 2010;269:136-47.

231 [8] Shvedova AA, Kisin E, Murray AR, Johnson VJ, Gorelik O, Arepalli S, et al. Inhalation vs. 232 aspiration of single-walled carbon nanotubes in C57BL/6 mice: inflammation, fibrosis, 233 oxidative stress, and mutagenesis. Am J Physiol Lung Cell Mol Physiol. 2008;295:L552-65.

234 [9] Takagi A, Hirose A, Nishimura T, Fukumori N, Ogata A, Ohashi N, et al. Induction of 235 mesothelioma in p53+/- mouse by intraperitoneal application of multi-wall carbon nanotube. 
J Toxicol Sci. 2008;33:105-16.

237 [10] Poland CA, Duffin R, Kinloch I, Maynard A, Wallace WA, Seaton A, et al. Carbon

238 nanotubes introduced into the abdominal cavity of mice show asbestos-like pathogenicity in 239 a pilot study. Nat Nanotechnol. 2008;3:423-8.

240 [11] Donaldson K, Stone V, Seaton A, Tran L, Aitken R, Poland C. Re: Induction of 241 mesothelioma in p53+/- mouse by intraperitoneal application of multi-wall carbon nanotube.

242 J Toxicol Sci. 2008;33:385; author reply 6-8.

243 [12] Ichihara G, Castranova V, Tanioka A, Miyazawa K. Re: Induction of mesothelioma in 244 p53+/- mouse by intraperitoneal application of multi-wall carbon nanotube. J Toxicol Sci. 245 2008;33:381-2; author reply 2-4.

246 [13] Muller J, Delos M, Panin N, Rabolli V, Huaux F, Lison D. Absence of carcinogenic 247 response to multiwall carbon nanotubes in a 2-year bioassay in the peritoneal cavity of the 248 rat. Toxicol Sci. 2009;110:442-8.

249 [14] Tabet L, Bussy C, Amara N, Setyan A, Grodet A, Rossi MJ, et al. Adverse effects of 250 industrial multiwalled carbon nanotubes on human pulmonary cells. J Toxicol Environ 251 Health A. 2009;72:60-73.

252 [15] Tian F, Cui D, Schwarz H, Estrada GG, Kobayashi H. Cytotoxicity of single-wall carbon 253 nanotubes on human fibroblasts. Toxicol In Vitro. 2006;20:1202-12.

254 [16] Raffa V, Ciofani G, Vittorio O, Riggio C, Cuschieri A. Physicochemical properties 255 affecting cellular uptake of carbon nanotubes. Nanomedicine (Lond). 2010;5:89-97.

256 [17] Soto K, Garza KM, Murr LE. Cytotoxic effects of aggregated nanomaterials. Acta 257 Biomater. 2007;3:351-8.

258 [18] Inoue K, Takano H, Koike E, Yanagisawa R, Sakurai M, Tasaka S, et al. Effects of 259 pulmonary exposure to carbon nanotubes on lung and systemic inflammation with 260 coagulatory disturbance induced by lipopolysaccharide in mice. Exp Biol Med (Maywood). $261 \quad 2008 ; 233: 1583-90$.

262 [19] Walker VG, Li Z, Hulderman T, Schwegler-Berry D, Kashon ML, Simeonova PP. 263 Potential in vitro effects of carbon nanotubes on human aortic endothelial cells. Toxicol Appl 264 Pharmacol. 2009;236:319-28.

$265[20] \mathrm{Hu}$ X, Cook S, Wang P, Hwang HM, Liu X, Williams QL. In vitro evaluation of 266 cytotoxicity of engineered carbon nanotubes in selected human cell lines. Sci Total Environ. $267 \quad 2010 ; 408: 1812^{-7}$.

268 [21] Herzog E, Byrne HJ, Davoren M, Casey A, Duschl A, Oostingh GJ. Dispersion medium 269 modulates oxidative stress response of human lung epithelial cells upon exposure to carbon 270 nanomaterial samples. Toxicol Appl Pharmacol. 2009;236:276-81.

271 [22] Kolosnjaj-Tabi J, Hartman KB, Boudjemaa S, Ananta JS, Morgant G, Szwarc H, et al. 
272 In vivo behavior of large doses of ultrashort and full-length single-walled carbon nanotubes

273 after oral and intraperitoneal administration to Swiss mice. ACS Nano. 2010;4:1481-92.

274 [23] Guo L, Morris D, Liu X, Vaslet C, Hurt R, Kane A. Iron bioavailability and redox 275 activity in diverse carbon nanotube samples. Chem Mater. 2007;19:3472-8.

276 [24] Kagan VE, Tyurina YY, Tyurin VA, Konduru NV, Potapovich AI, Osipov AN, et al. Direct 277 and indirect effects of single walled carbon nanotubes on RAW 264.7 macrophages: role of 278 iron. Toxicol Lett. 2006;165:88-100.

279 [25] Lindberg HK, Falck GC, Suhonen S, Vippola M, Vanhala E, Catalan J, et al. 280 Genotoxicity of nanomaterials: DNA damage and micronuclei induced by carbon nanotubes 281 and graphite nanofibres in human bronchial epithelial cells in vitro. Toxicol Lett. 282 2009;186:166-73.

283 [26] Rice JM, Kovatch RM, Anderson LM. Intraperitoneal mesotheliomas induced in mice by 284 a polycyclic aromatic hydrocarbon. J Toxicol Environ Health. 1989;27:153-60.

285 [27] Bocchetta M, Di Resta I, Powers A, Fresco R, Tosolini A, Testa JR, et al. Human 286 mesothelial cells are unusually susceptible to simian virus 40-mediated transformation and 287 asbestos cocarcinogenicity. Proc Natl Acad Sci U S A. 2000;97:10214-9.

288 [28] Carbone M, Kratzke RA, Testa JR. The pathogenesis of mesothelioma. Semin Oncol. $289 \quad 2002 ; 29: 2-17$.

290 [29] Xu L, Flynn BJ, Ungar S, Pass HI, Linnainmaa K, Mattson K, et al. Asbestos induction 291 of extended lifespan in normal human mesothelial cells: interindividual susceptibility and 292 SV40 T antigen. Carcinogenesis. 1999;20:773-83.

293 [30] Yang H, Testa JR, Carbone M. Mesothelioma epidemiology, carcinogenesis, and 294 pathogenesis. Curr Treat Options Oncol. 2008;9:147-57.

295 [31] Tanaka I. Respiratory tract deposition and clearance of inhaled particles in laboratory 296 animals. J Aerosol Res Japan 1988;3:104-10

297 [32] Witzmann FA, Monteiro-Riviere NA. Multi-walled carbon nanotube exposure alters 298 protein expression in human keratinocytes. Nanomedicine. 2006;2:158-68.

299 [33] Chang CC, Chen SH, Ho SH, Yang CY, Wang HD, Tsai ML. Proteomic analysis of 300 proteins from bronchoalveolar lavage fluid reveals the action mechanism of ultrafine carbon 301 black-induced lung injury in mice. Proteomics. 2007;7:4388-97.

302 [34] Witzmann FA, Monteiro-Riviere NA, Inman AO, Kimpel MA, Pedrick NM, Ringham HN, 303 et al. Effect of JP-8 jet fuel exposure on protein expression in human keratinocyte cells in 304 culture. Toxicol Lett. 2005;160:8-21.

305 [35] Haniu H, Komori N, Takemori N, Singh A, Ash JD, Matsumoto H. Proteomic trajectory 306 mapping of biological transformation: Application to developmental mouse retina. 307 Proteomics. 2006;6:3251-61. 
[36] Haniu H, Matsuda Y, Takeuchi K. Potential of a novel safety evaluation of nanomaterials using a proteomic approach. J Health Sci. 2009;55:428-34.

310 [37] Haniu H, Matsuda Y, Takeuchi K, Kim YA, Hayashi T, Endo M. Proteomics-based safety 311 evaluation of multi-walled carbon nanotubes. Toxicol Appl Pharmacol. 2010;242:256-62.

312 [38] Swisher JF, Burton N, Bacot SM, Vogel SN, Feldman GM. Annexin A2 tetramer 313 activates human and murine macrophages through TLR4. Blood. 2010;115:549-58.

314 [39] Shitama T, Hayashi H, Noge S, Uchio E, Oshima K, Haniu H, et al. Proteome Profiling 315 of Vitreoretinal Diseases by Cluster Analysis. Proteomics Clin Appl. 2008;2:1265-80.

316 [40] Bard MP, Hegmans JP, Hemmes A, Luider TM, Willemsen R, Severijnen LA, et al. 317 Proteomic analysis of exosomes isolated from human malignant pleural effusions. Am J 318 Respir Cell Mol Biol. 2004;31:114-21.

319 [41] Yanagisawa K, Shyr Y, Xu BJ, Massion PP, Larsen PH, White BC, et al. Proteomic 320 patterns of tumour subsets in non-small-cell lung cancer. Lancet. 2003;362:433-9.

321 [42] Suzuki T, Nagai R. Cardiovascular proteomic analysis. J Chromatogr B Analyt Technol 322 Biomed Life Sci. 2007;855:28-34.

323 [43] Negishi A, Ono M, Handa Y, Kato H, Yamashita K, Honda K, et al. Large-scale 324 quantitative clinical proteomics by label-free liquid chromatography and mass spectrometry. 325 Cancer Sci. 2009;100:514-9.

326 [44] Ellinger-Ziegelbauer H, Pauluhn J. Pulmonary toxicity of multi-walled carbon 327 nanotubes (Baytubes(R)) relative to [alpha]-quartz following a single $6 \mathrm{~h}$ inhalation 328 exposure of rats and a 3 months post-exposure period. Toxicology. 2009;266:16-29.

329 [45] Muller J, Huaux F, Fonseca A, Nagy JB, Moreau N, Delos M, et al. Structural defects 330 play a major role in the acute lung toxicity of multiwall carbon nanotubes: toxicological 331 aspects. Chem Res Toxicol. 2008;21:1698-705.

332 [46] Ma-Hock L, Treumann S, Strauss V, Brill S, Luizi F, Mertler M, et al. Inhalation toxicity 333 of multiwall carbon nanotubes in rats exposed for 3 months. Toxicol Sci. 2009;112:468-81.

334 [47] Sakamoto Y, Nakae D, Fukumori N, Tayama K, Maekawa A, Imai K, et al. Induction of 335 mesothelioma by a single intrascrotal administration of multi-wall carbon nanotube in 336 intact male Fischer 344 rats. J Toxicol Sci. 2009;34:65-76.

337 [48] Li JG, Li QN, Xu JY, Cai XQ, Liu RL, Li YJ, et al. The pulmonary toxicity of multi-wall 338 carbon nanotubes in mice 30 and 60 days after inhalation exposure. J Nanosci Nanotechnol. $339 \quad$ 2009;9:1384-7.

340 [49] Li XY, Brown D, Smith S, MacNee W, Donaldson K. Short-term inflammatory responses 341 following intratracheal instillation of fine and ultrafine carbon black in rats. Inhal Toxicol. 342 1999;11:709-31.

343 [50] Magrez A, Kasas S, Salicio V, Pasquier N, Schwaller B, Forrò L. Cellular toxicity of 
344 carbon-based nanomaterials. Nano Lett. 2006;6:1121-5.

345 [51] Jia G, Wang H, Yan L, Wang X, Pei R, Yan T, et al. Cytotoxicity of carbon nanomaterials:

346 single-wall nanotube, multi-wall nanotube, and fullerene. Environ Sci Technol.

347 2005;39:1378-83.

348 [52] Casey A, Herzog E, Lyng FM, Byrne HJ, Chambers G, Davoren M. Single walled carbon

349 nanotubes induce indirect cytotoxicity by medium depletion in A549 lung cells. Toxicol Lett.

$350 \quad 2008 ; 179: 78-84$.

351 [53] Herzog E, Byrne HJ, Casey A, Davoren M, Lenz AG, Maier KL, et al. SWCNT suppress

352 inflammatory mediator responses in human lung epithelium in vitro. Toxicol Appl

353 Pharmacol. 2009;234:378-90.

354 [54] Lindberg HK, Falck GC, Suhonen S, Vippola M, Vanhala E, Catalan J, et al.

355 Genotoxicity of nanomaterials: DNA damage and micronuclei induced by carbon nanotubes

356 and graphite nanofibres in human bronchial epithelial cells in vitro. Toxicol Lett.

$357 \quad 2009 ; 186: 166-73$.

358 [55] Mroz RM, Schins RP, Li H, Drost EM, Macnee W, Donaldson K. Nanoparticle carbon

359 black driven DNA damage induces growth arrest and AP-1 and NFkappaB DNA binding in

360 lung epithelial A549 cell line. J Physiol Pharmacol. 2007;58 Suppl 5:461-70.

361

362 


\section{Figure Legends}

364 Figure 1. Proteome map [36, 37]. Numbered spots were changed by more than two-fold

365 with statistically significant differences $(p<0.05)$ in cells treated with HTT1800,

366 HTT2800 or CB as compared to the control cells $(n=4)$. 
Table 1. Summary of recent toxicological evaluation in carbon nanomaterials

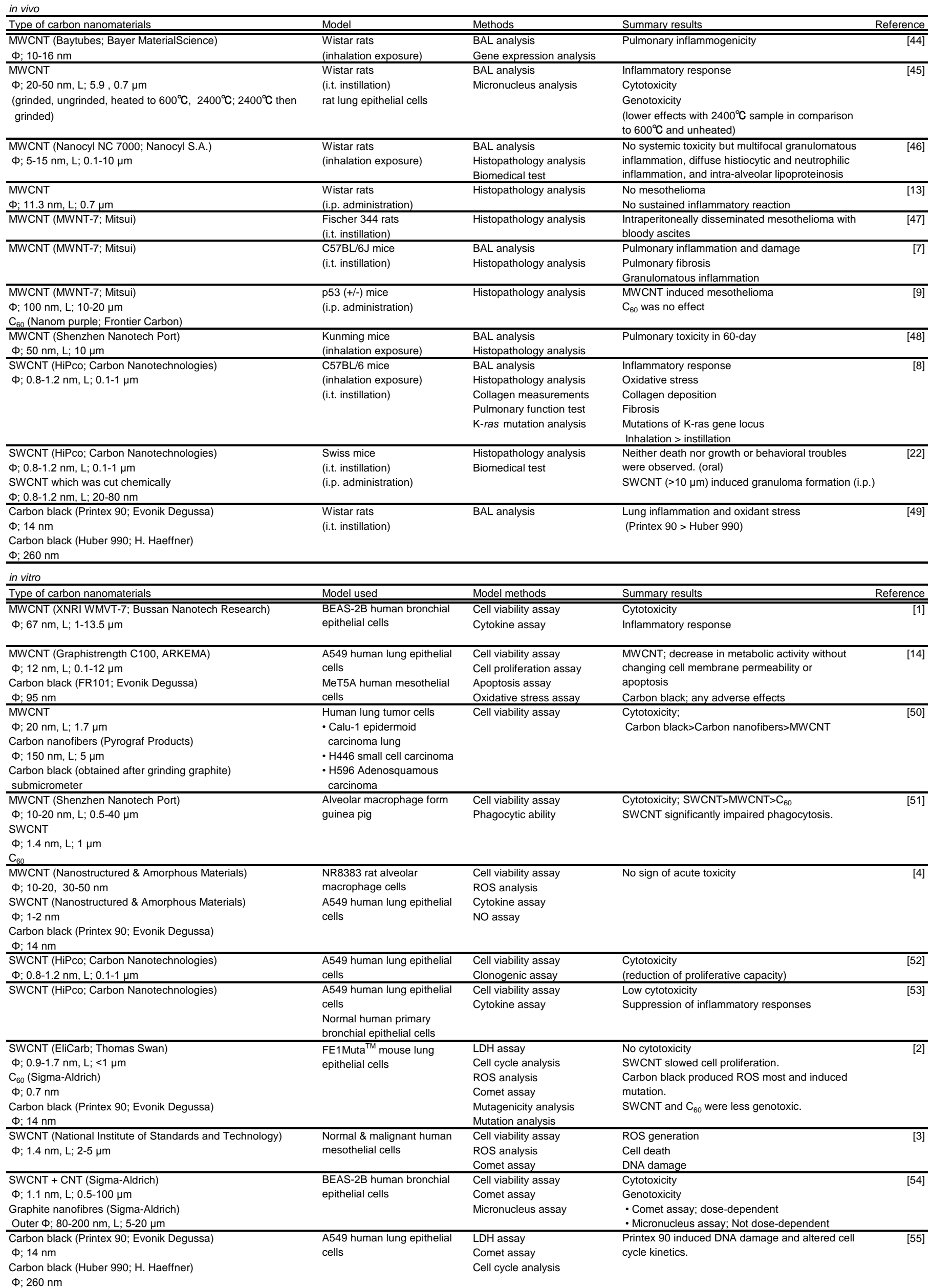

$\Phi ; 260 \mathrm{~nm}$

$\Phi$; diameter, L; length, $\mathrm{C}_{60}$; fullerene, i.t.; intratracheal, i.p.; intraperitoneal, BAL; bronchoalveolar lavage, ROS; reactive oxygen species, LDH; lactate dehydrogenase 
Table 2. Basic properties of multi-walled carbon nanotubes [37]

\begin{tabular}{lcccc}
\hline & As-grown & HTT1800 & HTT2800 & Testing method \\
\hline Diameter $(\mathrm{nm})$ & $100-150$ & $100-150$ & $100-150$ & FE-SEM \\
Length $(\mu \mathrm{m})$ & $10-20$ & $10-20$ & $10-20$ & FE-SEM \\
$\mathrm{d}_{002}(\AA)$ & - & - & 0.339 & X-ray diffraction \\
$\mathrm{R}$ value $\left(I_{\mathrm{d}} / I^{\mathrm{a}}{ }^{\mathrm{a}}\right.$ & 1.041 & 0.855 & 0.051 & Raman spectroscopy \\
Specific surface area $\left(\mathrm{m}^{2} / \mathrm{g}\right)$ & - & 26 & 13 & $\mathrm{~N}_{2}$ adsorption \\
Real density $\left(\mathrm{g} / \mathrm{cm}^{3}\right)$ & - & - & 2.09 & Pycnometer \\
Iron content $(\mathrm{ppm})$ & 12,000 & 80 & $<20$ & ICP-MS \\
Soluble iron content $(\%)^{\mathrm{b}}$ & 0 & 91 & 100 & ICP-MS \\
Polycyclic aromatic hydrocarbons $(\mathrm{wt} \%)^{\mathrm{c}}$ & 0.19 & None & None & GC-MS \\
Oxidation temperature $\left({ }^{\circ} \mathrm{C}\right)^{\mathrm{d}}$ & 630 & 720 & 820 & TGA \\
\hline
\end{tabular}

a $R$ refers to the intensity of $D$ band over the intensity of $G$ band.

$\mathrm{b}$ We have determined the dissolved amount of iron by refluxing $5 \mathrm{~g}$ of nanotubes in hydrochloric acid $(0.6 \mathrm{~N})$ for $25 \mathrm{~h}$.

c We have measured acetone-soluble components.

$d$ We have determined the oxidation temperatures via the derivation of TGA curve.

FE-SEM; Field emission-scanning electron microscopy, ICP-MS; Inductively coupled plasma-mass spectrometry,

GC-MS; Gas chromatograph-mass spectrometry, TGA; Thermogravimetric analysis 


\begin{tabular}{|c|c|c|c|c|c|c|c|c|c|}
\hline \multirow{2}{*}{$\begin{array}{c}\text { Spot } \\
\text { No. }\end{array}$} & \multirow[b]{2}{*}{ Protein Name } & \multirow[b]{2}{*}{$\begin{array}{l}\text { Theoritical } \\
\text { MW }\end{array}$} & \multirow[b]{2}{*}{$\begin{array}{l}\text { Theoritical } \\
\text { pl }\end{array}$} & \multirow[b]{2}{*}{$\begin{array}{l}\text { MOWSE } \\
\text { Score }\end{array}$} & \multirow[b]{2}{*}{ Coverage } & \multirow[b]{2}{*}{$\begin{array}{l}\text { Matched } \\
\text { Peak }\end{array}$} & \multicolumn{3}{|c|}{ Ratio } \\
\hline & & & & & & & $\begin{array}{l}\mathrm{HTT} \\
1800\end{array}$ & $\begin{array}{l}\mathrm{HTT} \\
2800\end{array}$ & $\begin{array}{l}\text { Carbon } \\
\text { black }\end{array}$ \\
\hline 1 & $\begin{array}{l}\text { heterogeneous nuclear ribonucleoprotein } \\
\text { A2/B1 }\end{array}$ & 37478 & 8.97 & 141 & $43 \%$ & $14 / 18$ & *2.12 & $\# 1.45$ & 1.08 \\
\hline 2 & DnaJ homolog subfamily $\mathrm{C}$ member 8 & 29823 & 9.04 & 89 & $28 \%$ & $10 / 12$ & 1.00 & 0.74 & * 0.42 \\
\hline 3 & small nuclear ribonucleoprotein polypeptide $A^{\prime}$ & 28540 & 8.72 & 97 & $29 \%$ & $8 / 11$ & ${ }^{*} 0.23$ & 0.55 & 0.30 \\
\hline 4 & proteasome subunit $\beta$ type-1 & 26757 & 8.27 & 82 & $27 \%$ & $7 / 8$ & ${ }^{*} 0.36$ & \# 0.59 & 0.76 \\
\hline 5 & annexin A2 & 38864 & 7.57 & 114 & $28 \%$ & $11 / 12$ & * 3.58 & 2.50 & * 0.34 \\
\hline 6 & vasodilator-stimulated phosphoprotein & 39977 & 9.05 & 78 & $24 \%$ & $8 / 15$ & * 3.20 & 1.58 & 3.21 \\
\hline 7 & heterogeneous nuclear ribonucleoprotein $\mathrm{M}$ & 77819 & 8.84 & 186 & $32 \%$ & $24 / 26$ & * 2.01 & 1.25 & 1.23 \\
\hline 8 & phosphatidylethanolamine-binding protein 1 & 21186 & 7.01 & 107 & $45 \%$ & $8 / 13$ & * 0.35 & ${ }^{*} 0.44$ & 0.87 \\
\hline 9 & flavin reductase & 22248 & 7.13 & 74 & $40 \%$ & $6 / 9$ & ${ }^{*} 0.13$ & 0.42 & 0.68 \\
\hline 10 & pyruvate kinase isozymes M1/M2 & 58664 & 7.60 & 129 & $16 \%$ & $14 / 14$ & * 2.62 & 1.29 & 1.82 \\
\hline 11 & transketolase & 68687 & 7.58 & 242 & $30 \%$ & $23 / 25$ & * 2.22 & 1.84 & 1.37 \\
\hline 12 & proteasome subunit $\alpha$ type-2 & 26024 & 6.92 & 76 & $17 \%$ & $6 / 9$ & ${ }^{*} 0.47$ & 0.56 & 0.69 \\
\hline 13 & triosephosphate isomerase & 27008 & 6.45 & 134 & $42 \%$ & $11 / 15$ & ${ }^{*} 0.43$ & ${ }^{*} 0.45$ & 0.77 \\
\hline 14 & phosphoglycerate mutase 1 & 28928 & 6.67 & 84 & $20 \%$ & $6 / 6$ & ${ }^{*} 0.49$ & \# 0.51 & \# 0.71 \\
\hline 15 & actin related protein $2 / 3$ complex subunit 2 & 34454 & 6.84 & 72 & $19 \%$ & $8 / 16$ & 0.88 & \# 0.60 & ${ }^{*} 0.49$ \\
\hline 16 & actin related protein $2 / 3$ complex subunit 2 & 34454 & 6.84 & 72 & $19 \%$ & $7 / 10$ & 0.59 & ${ }^{*} 0.50$ & 1.22 \\
\hline 17 & $\begin{array}{l}\text { 6-phosphogluconate dehydrogenase, } \\
\text { decarboxylating }\end{array}$ & 53745 & 6.80 & 71 & $12 \%$ & $6 / 6$ & 0.58 & ${ }^{*} 0.49$ & * 0.47 \\
\hline 18 & far upstream element-binding protein 2 & 73542 & 6.84 & 140 & $22 \%$ & $12 / 13$ & * 2.35 & 2.06 & 1.20 \\
\hline 19 & cytosolic malate dehydrogenase & 36687 & 6.91 & 87 & $20 \%$ & $9 / 11$ & ${ }^{*} 0.49$ & \# 0.65 & 0.84 \\
\hline 20 & $\operatorname{lamin} A / C$ & 65167 & 6.40 & 193 & $34 \%$ & $19 / 19$ & 1.73 & * 2.47 & 0.84 \\
\hline 21 & mitochondrial import receptor subunit TOM70 & 68264 & 6.75 & 69 & $12 \%$ & $7 / 8$ & * 2.34 & 1.81 & 0.87 \\
\hline 22 & polyribonucleotide nucleotidyltransferase 1 & 86664 & 7.87 & 86 & $13 \%$ & $12 / 18$ & * 2.32 & 1.82 & 0.88 \\
\hline 23 & $\delta$-1-pyrroline-5-carboxylate synthetase & 88171 & 6.66 & 87 & $9 \%$ & $8 / 8$ & * 2.10 & \# 1.79 & 1.50 \\
\hline 24 & transaldolase & 37730 & 6.36 & 167 & $36 \%$ & $16 / 18$ & * 0.45 & 0.58 & 0.69 \\
\hline 25 & squalene synthetase & 48724 & 6.10 & 68 & $17 \%$ & $8 / 12$ & ${ }^{*} 0.47$ & 0.65 & 0.98 \\
\hline 26 & a-ketoglutarate dehydrogenase & 117353 & 6.40 & 119 & $12 \%$ & $14 / 15$ & ${ }^{*} 4.13$ & ${ }^{*} 4.10$ & 1.02 \\
\hline 27 & protein DJ-1 & 20092 & 6.33 & 114 & $43 \%$ & $12 / 13$ & ${ }^{*} 0.42$ & ${ }^{*} 0.35$ & 0.89 \\
\hline 28 & heat shock protein $\beta-1$ & 22840 & 5.98 & 90 & $26 \%$ & $8 / 9$ & \# 0.59 & ${ }^{*} 0.42$ & 0.92 \\
\hline 29 & transaldolase 1 & 37730 & 6.36 & 150 & $29 \%$ & $14 / 15$ & ${ }^{*} 0.35$ & 0.46 & 0.66 \\
\hline 30 & $\begin{array}{l}\text { serine/threonine-protein phosphatase PP1- } \alpha \\
\text { catalytic subunit }\end{array}$ & 38411 & 5.94 & 120 & $34 \%$ & $11 / 18$ & \# 0.52 & ${ }^{*} 0.29$ & 0.92 \\
\hline 31 & leukocyte elastase inhibitor & 42857 & 5.90 & 133 & $32 \%$ & $13 / 14$ & 0.65 & ${ }^{*} 0.48$ & 0.99 \\
\hline 32 & $\begin{array}{l}\text { serine/threonine-protein phosphatase } 2 A 55 \\
\mathrm{kDa} \text { regulatory subunit } \mathrm{B} \alpha \text { isoform }\end{array}$ & 52299 & 5.82 & 103 & $16 \%$ & $9 / 10$ & 0.72 & ${ }^{*} 0.49$ & 1.20 \\
\hline 33 & interferon-induced protein 53 & 49247 & 6.03 & 76 & $10 \%$ & $6 / 6$ & ${ }^{*} 0.43$ & 0.80 & 0.78 \\
\hline 34 & DNA mismatch repair protein Msh2 & 105600 & 5.58 & 69 & $10 \%$ & $9 / 12$ & * 3.13 & * 3.78 & 1.97 \\
\hline 35 & neutral $\alpha$-glucosidase $A B$ & 107375 & 5.74 & 183 & $19 \%$ & $21 / 24$ & * 3.09 & * 3.05 & 2.15 \\
\hline 36 & F-actin capping protein subunit $\beta$ & 31036 & 5.69 & 104 & $26 \%$ & $10 / 13$ & ${ }^{*} 0.36$ & 0.42 & 1.34 \\
\hline 37 & Thioredoxin domain-containing protein 5 & 44636 & 5.77 & 68 & $12 \%$ & $6 / 8$ & 1.21 & 1.04 & * 0.20 \\
\hline 38 & heat shock protein 60 & 61229 & 5.70 & 172 & $28 \%$ & $15 / 15$ & * 2.70 & 1.43 & 1.70 \\
\hline 39 & lamin-B2 & 67790 & 5.29 & 183 & $31 \%$ & $19 / 19$ & * 2.44 & 1.71 & 0.99 \\
\hline 40 & 14-3-3 protein $v$ & 28498 & 4.80 & 150 & $36 \%$ & $16 / 19$ & \# 0.50 & ${ }^{*} 0.48$ & * 0.39 \\
\hline 41 & elongation factor $1-\delta$ & 31245 & 4.90 & 124 & $34 \%$ & $8 / 8$ & 0.33 & ${ }^{*} 0.18$ & 0.53 \\
\hline 42 & Ubiquitin thioesterase OTUB1 & 31549 & 4.85 & 81 & $26 \%$ & $6 / 8$ & 0.48 & 0.23 & * 0.23 \\
\hline 43 & Spermine synthase & 24942 & 5.16 & 71 & $19 \%$ & $6 / 10$ & 0.68 & 0.67 & * 0.34 \\
\hline 44 & splicing factor $3 \mathrm{~A}$ subunit 3 & 59238 & 5.27 & 76 & $14 \%$ & $9 / 10$ & 1.60 & 1.52 & * 0.46 \\
\hline 45 & $78 \mathrm{kDa}$ glucose-regulated protein & 72431 & 5.07 & 176 & $27 \%$ & $19 / 20$ & * 2.33 & 1.27 & 0.73 \\
\hline 46 & transportin 1 & 103091 & 4.81 & 102 & $13 \%$ & $12 / 15$ & 1.47 & 4.35 & * 3.80 \\
\hline 47 & DNA damage-binding protein 1 & 128470 & 5.16 & 84 & $7 \%$ & $10 / 11$ & 2.10 & * 2.82 & 1.82 \\
\hline 48 & 14-3-3 protein $\varepsilon$ & 29369 & 4.63 & 150 & $43 \%$ & $17 / 21$ & ${ }^{\star} 0.41$ & 0.59 & 0.89 \\
\hline 49 & proliferating cell nuclear antigen & 29177 & 4.57 & 115 & $28 \%$ & $12 / 15$ & ${ }^{*} 0.47$ & 0.63 & 0.78 \\
\hline 50 & splicing factor SC35 & 25461 & 11.86 & 100 & $38 \%$ & $10 / 12$ & ${ }^{*} 0.27$ & 0.30 & 1.02 \\
\hline 51 & ribonuclease inhibitor & 52214 & 4.71 & 68 & $15 \%$ & $6 / 8$ & ${ }^{*} 0.44$ & 0.61 & 0.61 \\
\hline 52 & calreticulin & 48325 & 4.29 & 68 & $13 \%$ & $6 / 8$ & * 4.88 & 1.52 & 12.02 \\
\hline
\end{tabular}

Ratios of protein expression were compared to the control. $n=4$. ${ }^{*} ; p<0.05$ and two-fold change, \#; $p<0.05$ only 
Figure
Click here to download high resolution image

Figure 1

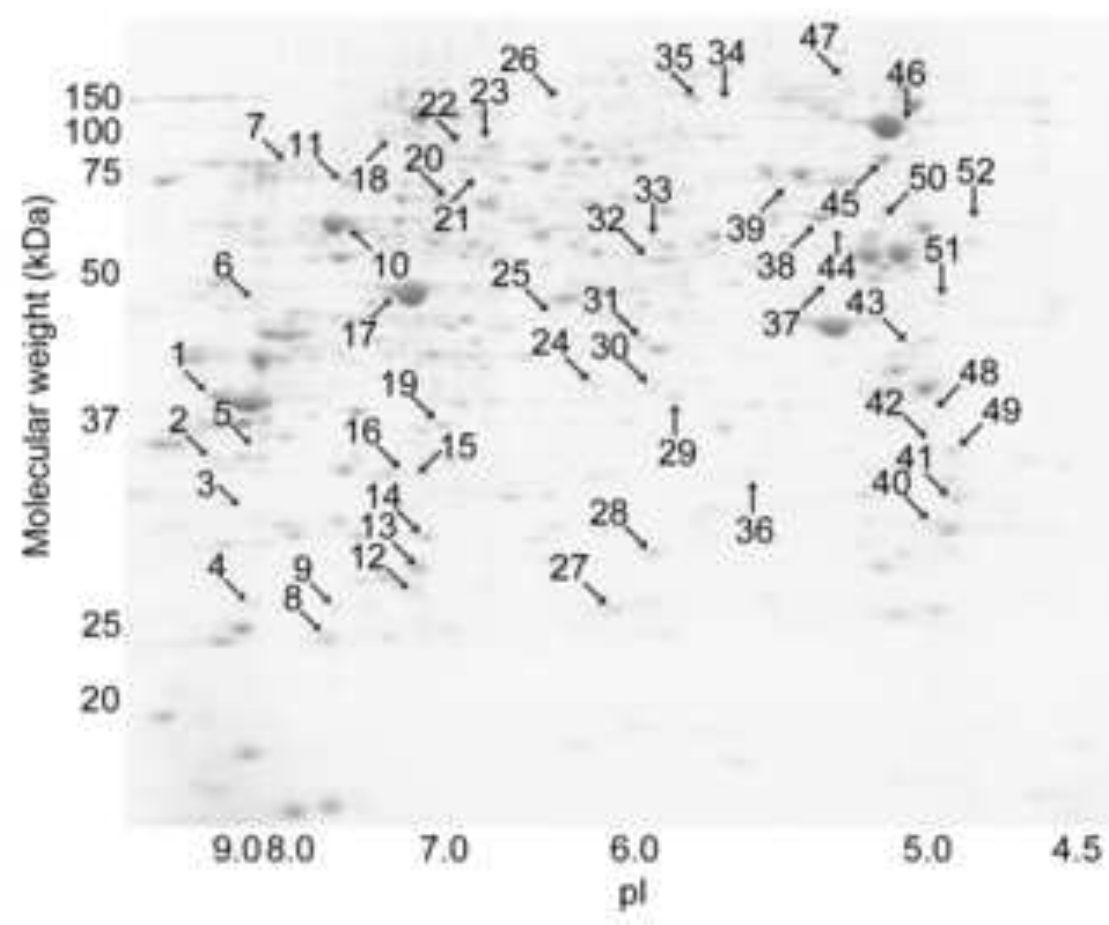

